\title{
Manuscript Suluk Wujil: Values Tansformation of Tassawuf Education Sunan Bonang in Nation Character Building
}

\author{
M Haris Mahfudh*; Hermanu Joebagio; Mulyoto \\ ${ }^{2}$ Department of Teaching and Training Education, Sebelas Maret University, Indonesia \\ Email: haris_mahfudh91@yahoo.co.id
}

http://dx.doi.org/10.18415/ijmmu.v4i4.75

\begin{abstract}
This study examines the process of implementing the development of historical learning with the values of Suluk Wujil to increase social solidarity. Transformation of an educational value can be done through collaborative learning models with educational character values. Teachers play a role in stimulating students to understand the values of Suluk Wujil. Local wisdom has an important role in moral education. Suluk Wujil is a relic of Islamic history in the form of a manuscript containing the discourse of Sunan Bonang to Wujil, a servant of the State of Majapahit. A social solidarity attitude is needed in a heterogeneous society. Historical learning model of historical manuscripts that can facilitate students in taking the values contained in the manuscript. Wujil's Wisdom values include loyalty, sincerity, religion, responsibility, and self-identification.
\end{abstract}

Keywords: Character education; Wujil suluk; Social solidarity

\section{Introduction}

The principle of education is the process of cultivating students that lasts throughout life on the basis of compassion. Teachers have multiple tasks and functions in the education process, ie as teachers and second parents for students at school. Education is all effort and effort to make students can develop the potential to have spirituals power, self-control, personality, intelligence, noble character, and possess necessary skill as member of society and citizen (Majid, 2014). The purpose of education is not just to teach science, but to establish a sense of personality to instill patriotism in the individual. Patriotism is a solid foundation for encouraging people to establish a society that has a civilization. Al-Tahtawi was an Egyptian who first advocated patriotism. The idea that the whole world of Islam is the homeland of Muslims, but now has changed the meaning of the homeland. The homeland is now emphasized on one's blood soil no longer means the whole Islamic world. So there are two fraternities, the fraternity of the homeland and the Islamic brotherhood. For Al-Tahtawi which is more important than the two is not clear. The development of the Islamic world makes the fraternity of the land more powerful. The word watan and hub al-watan are always used by Al-Tahtawi in his book. This explains that one's duty to his / her homeland involves union, submission to the law and the willingness to sacrifice property and self. Independence can manifest a genuine unity of society and a strong sense of patriotism (Nasution, 1987). 
Hurlock says that to achieve emotional maturity, adolescents must learn to get a picture of situations that can generate emotional reactions and must learn to use emotional catharsis. According to Yusuf to achieve emotional maturity is a very difficult development task for teenagers. The process of achievement is strongly influenced by socioemosional scope, especially the family environment and peers Adolescence has the task to prepare themselves to enter the next stage of development, namely adults. Their future depends on the effectiveness of their preparation for entering into adulthood (Yusuf, 2012). Emotional maturity or called emotional maturity is a state or condition that reaches the maturity level of emotional development and therefore the person concerned does not come up with an appropriate emotional pattern for the children. The term maturity or emotional maturity often brings the implications of emotional control. Where some of the adults have the same emotions as children, they are able to better control or control them, especially in the midst of social situations (Chaplin, J.P, 2011). This period is higher when compared to when they were in kindergarten, elementary, junior high school when the role of parents is much larger in planning and determining the steps to be taken to enter the next stage. In this high school period they are required to be more independent in planning their future. The level of education after high school usually has a pattern that directly educates to serious in one field of discipline (Maria, 2008). Successfully complete the establishment In this development will assist the individual in completing the next development task. Conversely, failure to achieve this priode development will hinder the progress of the next period (Supriatna. Dkk, 2009).

A superior nation is a nation capable of maintaining identity as an independent and independent nation. Maintaining, increasing social capital, considering togetherness, solidarity, solidarity, mutual cooperation, trust (Trust) becomes the absolute requirement in realizing every sector of development (Maryani, E \&Syamsuddin, H 2009). In economics, capital is something that is profitable and productive. This capital is divided into three namely, first, the capital in the form of money include money, goods or buildings. Second, cultural capital in the form of quality education and local cultural wisdom. Third, social capital in the form of togetherness, social obligations are instructed in the form of life together, roles, authority, responsibility, reward system and other interests that result in collective action.

According Dilthey history as a science is divided into two namely Naturwissenschaften (natural sciences) and Geisteswissenssenschaften (humanities, humanities, human studies and cultural sciences). Ditley also explained that man can only be understood through the concept of life, not from the abstract concepts of Naturwissenschaften and man is a historical being, because it can only be explained through its history. Verstehen's concept is an experience in penetrating the soul and the whole Human experience. Understanding of an institution, the laws of theory, art, values can be exposed through paper, ink, stone, and all man-made cultural goods. Humans can understand the inner meaning of symbolic objects such as crosses, flags, constitutions or rebellions, with reference to the meaning behind human life. The hidden things are understandable though often unexplainable (Kuntowijoyo, 2008). According Widja Learning history is a picture of past events under the educators into the classroom and not all historical events can be taught to students the events that contribute to determine the course of history of mankind (Widja, 1989). This is according to research by Widia about LKS history of students which contains the history lesson that memorize, thus making students quickly saturated with history lesson. The lesson of history requires an appropriate learning concept to be able to give students the significance of a historical event based on the values contained in the event (Widia, A.D, 2011). Kuntowijoyo argues that lessons containing moral messages must have different approaches, so history is not boring because there are many repetitions. Lessons in high school history lessons must begin to be transmitted, submitted must develop a student's critical attitude. Students are required to be able to think why it can happen, what exactly has happened, and where the direction of the incident. From the above understanding It can be concluded that history is an event that has occurred about science containing moral messages in studying it often using various approaches to explain a historical event (Kuntowijoyo, 2013). 
According to Hermanu historical learning is the process of internalizing the values of past events, in the form of origins, genealogy, collective experience, and exemplary history. The lesson is designed to form a wise and wise person, therefore historical learning demands a design that will produce quality output that includes understanding the events of the nation's history, imitating the wisdom, and the wisdom of the offender. Exemplary wisdom and wisdom will be obtained through the deepening activities of historical events, including the process of social-cultural, socio-economic, and socio-political relationships between actors and community groups (Brian\&Mary, 2015). Character is morality, or personality formed from the internalization of various policies (virtues) that are believed and used as a basis for the worldview, thinking, and acting (Hasan, S.H, dkk, 2010). Character education is a deliberate effort to develop good character based on good core values For individuals and good for society (Wibowo, A\&Purnama, 2013). Pendidikan karakter saat ini sangat relevan diterapkan dalam lingkungan keluarga dan sekolah sebagai wadah yang berpengaruh besar terhadap pembentukan karakter anak. Character education is currently very relevant applied in the family and school environment as a container that has a major impact on the formation of children's character. The lesson of history is a lesson that requires understanding and analysis. But in reality history lessons are a lesson in memorizing important events and dates. Research Kuban Seckin in 2015 on Bitig Irk is a manuscript or book of forecasts written by the Uigur. The manuscript consists of 65 paragraphs each of which is a different prophecy. Written on 12 centuries ago in spoken language. Through this text they provide insight into the political life of the ancient Turks, the governors of the kingdom, and religious beliefs. This study aims to determine the analysis of a work that reflects Turkish culture is very useful, so to know the meaning of historical transformation done more explicitly. In this case ideology, how the subject is positioned, which socially creates a good and bad understanding (Kuban Seckin, 2015).

\subsection{Transformation Character Education}

Transformation is a scientific concept or analysis tool for understanding the world. Because by understanding the changes at least two conditions / conditions that can be known that the state of prechange and post-change circumstances. Transformation is an effort done to preserve local wisdom in order to survive and can be enjoyed by the next generation so that they have a strong character in accordance with the character Implied by the ideology of Pancasila (Kuntowijoyo, 2006). Transformation involves changes in the web of social and ecological relationships. If the structure of the web is changed, there will be a transformation of social institutions, values and thoughts. Cultural transformation is related to the evolution of human culture. This transformation is typically preceded by a variety of social indicators. This cultural transformation is like an essential step in the development of civilization. All civilizations run through the similarity of cycle processes of events, growth, wholeness and integrity (Pujileksono, 2009). Local wisdom can be understood as a view of life and knowledge as well as various life strategies that are tangible activities undertaken by local communities. Thanks to local wisdom, they can live a life that can even grow sustainably (Permana 2010).

The formation of a character of social solidarity that needs to be built for the common good. Emile Durkheim believes there are two solidarities: (1) Organic solidarity: a form of solidarity that binds a complex society, that is, a society that recognizes a detailed division of labor united by interdependence between parts. (2) Mechanical Solidarity: all members of society are bound by collective consciousness, collective conscience that is a common consciousness that includes the whole beliefs and feelings of the group, and is extreme and coercive (Kamanto 2004). Ibn Khaldun explains the concept of social solidarity with the word Ashabiyah. Ashabiyah is a sense of social solidarity in which there are tribes or groups that cooperate for the common good. Strong Ashabiyah is a must for the foundation of a country's building. Rarely happens a country can stand in an area where there are various ethnic groups. Indonesia that has tribal diversity is important to create social solidarity in society. 


\subsection{Suluk Wujil Values}

The development of the history of religions will bring deep conviction for a person. It takes a religious historical approach to understanding and analyzing Islamic traditions, and understanding relationships between some elements such as structural relationships with other traditions (Ghazali, 2015). Islam brought to Java at that time was Islam followed by Sufism. The existence of color equations, namely Sufism ease the task of the preachers called walisongo in broadcast and teach Islam to the public so tend to accept (Warsito, 2015). The existence of tolerance of Sufi people in dealing with different views relating to local traditions and beliefs. The ancestors or Javanese ancestors who left the heritage of cultural identity are not only proud, but also have symbols that are full of essential values of life and life. In fact, the identity of Javanese culture also has usability (pragmatic), purpose, and symbolization Philosophy, in addition to its ethical and aesthetic values (Susetya, 2007). Javanese customs in religious ceremonies are not carried out with hustle and noise. The growing religion of Islam in Java seems to emphasize only the appearance and execution. As a nation the Javanese did not intend to feel hatred for Europeans whom they regarded as traitors as a simple example of where the teachings of Islam had entered into them. Javanese literary works during its development have characteristic tend to be religious mystical in the form of lyric prose or tembang Macapat. More complex works with Javanese-Hindu adaptations that are colored by Islami. Javanese literary works in its development can be divided into three characteristics of the group include: (1) works containing religious orthodox ethical themes and put forward Islamic law, (2) works in the form of didactic narrative poems; And (3) mystical works (Raffles, 2014).

In Wujil Suluk, Macapat song that is used is Dhandanggulo tembang, Mijil tembang, and Old Javanese song style is Aswawalita. It tells about a man named Wujil. Wujil was originally a royal servant in the Majapahit Kingdom. Because thirst for the science of religion he traveled from the kingdom of Majapahit then studied with Queen Wahdat (Another name of Sunan Bonang). Ten years of studying Wujil has not been given the secret teaching of science as he wishes. Finally Wujil dared to ask Queen Wahdat. Queen Wahdat explains that it is not yet time for the secret teachings studied by Wujil. Queen Wahdat wants people who learn the science of secret must prepare by having honest nature, born Inner, clean soul and body (Achmad, 2014). The following are the Values contained in Suluk Wujil:

\section{1) Loyalty}

The 2nd stanza in the Suluk Wujil script:

"Sadasa warsa sira even Wujil / Angasta padane Sangane Adiningrat / anantun warah dikane / ing feelingjilanipun / sira Wujil ing Maospahit / amêng-amênganira / nateng Majapahit / têlas sandining aksara / Wujil matur sira the adi gusti / anuwun Pangandika"

This Mean: Ten years of Wujil studied by the Great Panembahan, have not received the important doctrine, while originally, Wujil came from Majapahit as the king's favorite servant in Majapahit, graduated studied throughout the grammar, then Wujil said to the greatly honored The Panembahan with beg for forgiveness.

In these two verses explain the meaning of faithfulness, in this verse describes a faithful person waiting for the expectation of a teacher. Loyalty is a clear feeling to his mind or pure obedience to his self-control and to all the universes in which man resides, as well as a sense of obedience to the prevailing norms. It can be seen the loyalty of telling about Wujil who for ten years became a disciple of the great and none of whom he can. Though Wujil is the favorite servant of Majapahit (Apriana, 2015). 


\section{2) Sincerity}

The third verse in the Suluk Wujil script:

"Pun Wujil byate kang anuwun sih / ing têlapakan Teak Wati / ngaturkên pejah gêsange / sampun wening pamuruk / aras panduka warti / wêkasane alodrang agêng among kayun / sabên dina rêrakêtan / even bosên kawula kang aludjaga / ginawe alan-alan"

This mean: Wujil's servant sincerely pleads, in front of the teacher please be given a lesson, slave surrender life and death servant, has graduated the teacher's teaching in arabic language, still we searching, wandering following the will of heart, every day we are together, I laughed, became a pedestal.

The third verse in the Suluk Wujil Fiber text contains sincerity meaning. Sincere is leaving riya in various obedience with sincere feelings. Sincere contains the cleansing of the heart from the dirt that can muddy its properties In this verse describes someone who sincerely waiting for something even though boredom has hit, it is done because someone has the desire to achieve something desired. Despite having to wait, Wujil still has a sincere sense of resignation to his Lord (Achmad, 2014).

\section{3) Religious Values (Piety)}

Piety is morals to the creator who means obedience and love to Him, obeying means carrying out his commandments and avoiding his prohibitions which are accompanied by submission and submissive to Him. The following is the meaning of religiosity in the matter of piety contained in the text of the Suluk Wujil Fiber. The piety is contained in the Fiber Suluk Wujil as many as 18 indicators. Here's a quote in the Suluk Wujil Fiber. The 6th verse in the Suluk Wujil Fiber text:

"Pun Wujil byate kang anuwun sih / ing têlapakan Teak Wati / ngaturkên pejah gêsange / sampun wening pamuruk / literature arab panduka warti / wêkasane alodrang / agêng among kayun / sabên dina rêrakêtan / even bosên kawula kang aludjaga / ginawe alan-alan $/ / "$

This Mean: The Wujil was indeed begging for mercy, before the feet of the Lord, surrendering the life of the dead, increasingly overwhelmed by all the lessons, the Arabic literature that you taught, finally gone to the will of the heart, always following the will of the heart, every day playing mask, till the bored servant behave As a clown, has become a cornerstone of ridicule.

It is explained that Wujil hopes that God always puts all about one's life. And always surrender to God about all life and death that have been determined. Teaching about the steadiness of the heart of Wujil undertakes all the creator's commands and is told that Wujil has always been the cornerstone of ridicule from everyone. This can be categorized in the value of the religiosity of the creator towards the creator(Apriana, 2015). 


\section{4) Responsibility}

The eighth verse in the Suluk Wujil script:

"The Queen Wahdat lingira eyebrow / Hira ra Wujil mareng to den enggal / trus dencekel kekucire / sarwi den elus-elus / tiniban sih ing sabadi wadi / ra wujil rungokene / sasmita katengsun / seagrass sira kalebua / ing naraka ingsung dwewek angleboni / aja kang Rich sira // "

This Mean: The Arif said softly. "Hai Wujil, come here", holding Wujil's ponytail. Then also Stroked. Sign of affection. "Wujil, listen now! If you have to go to hell. Because of my words. I will replace your place" (Apriana, 2015).

In this 8th verse contains the meaning of Responsibility that is about someone who does anything should be based on Responsibility. Because this meaning teaches someone to take responsibility with what he has done.

\section{5) Honesty and Self Identification}

The 22nd stanza in the Suluk Wujil script:

"Sayogyane heh sira ra Wujil / deku ta mangke sariranira / ya kantiya nyayangi sautuhe / your neighbor iku / seaweed sira dera alah / sing kang real sarira / polahe ambesur / amarang rêraganira / kang dadi tingal ananging keki iki / kang den liling netyama"

This Mean: You better, now Wujil, know yourself. Really like your outstretched body, Wujil if you turn off who knows himself, his actions are not tired of imprisoning, which imprisoned his body, the only thing to notice is his shortcomings, which are constantly remembered.

In the 22nd stanza it contains the meaning of honesty that is about a person who does anything should be based with honesty, because the honesty can be seen from the circumstances that will be experienced. In this case can be reinforced with a translation on this stanza that tells about the honesty that Wujil did by likening to stretching the body and can be said to be honest with him (Purbatjaraka, 1985).

Suluk Wujil is one of the Javanese literature. Literature is very important in the life of the society, because literature is a proof that it has emerged since ancient times. Literature can not be separated from people who have a bureaucratic order society that can support the emergence of the very important archive. Literature is a new thing, because in ancient times there is still no role model of literature that can be used as a reference to create a literary work. Literature can be better understood as a historical relic. Historical relics are not only for knowledge, but a relic should be understood and taken into account its meaning. Historical relics can provide an understanding that the ancestral responsibilities in keeping the nation. Suluk Wujil has educational values that include: loyalty, sincerity, religious, responsibility, and honesty. The results of research on local wisdom conducted by Sariyatun (2012) about "IPS Learning Model based on the local cultural values of classical batik to improve the identity of the study nation in junior high school students in Surakarta" explained that by combining cooperative models with the values contained in classical batik Proving there is an increase in students' attitudes towards awareness of their nation (Sariyatun, 2012). 


\section{Methodology}

Researchers in this case developed a model of learning using the Dick and Carey model simplify into three phases of important, which starts from (1) an analysis learning needs, (2) developing learning models and materials in research, and (3) final stages of revision and evaluation, so as to find a model of history learning based on Suluk Wujil values for Increase students' social solidarity. Each step is done based on the type of research from the data source, data collection techniques, data analysis, subject, and time allocation of the study. The use of constructivism theory in the learning process of the students must be actively involved construct their own knowledge based on the experience or all objects of knowledge that exist in their environment. The learning steps of history based on Wujil's Wukil values to improve Social Solidarity collaboration with the Numbered-Head Together (NHT) cooperative model include several phases: (1) first: introduction; (2) second: Grouping; (3) third: plan and observe; (4) fourth: organizing; (5) fifth: numbering, discussion of results, and evaluation; (6) sixth: conclusion and conclusion.

Research and development (R \& D) in the field of education is a development research model that adapts the development of industrial products. The research findings are used to design new products and procedures, which are then systematically tested, evaluated and refined until the results meet the criteria in terms of the same effectiveness, quality, and standards (Gall, Gall \& Borg, 2003). Research and Development is defined as a method of research that systematically aims to discover, formulate, improve, develop, produce, test the effectiveness of new, new, effective, efficient, productive, and meaningful products, models, methods, services, certain procedures (Putra, 2012). Dick and Carey's model belongs to the procedural model. The steps of instruction design according to Dick and Carey are: identify the general objectives of learning, implement the learning analysis, identify the input behavior and characteristics of the students, formulate the objectives of the performance, develop the benchmark reference test, develop the learning strategy, develop and select the learning materials, Design and carry out formative evaluations, revise learning materials, design and implement summative evaluations. Researchers in this case develop a model of learning by using the Dick and Carey model to simplify into 3 important stages, which Starting with (1) analyzing the learning needs, (2) developing learning models and materials in the research, and (3) the final stages of revision and evaluation, so as to find a model of learning history of reinterpretation of Suluk Wujil values to improve students' social solidarity. Each step is based on the type of research, from data sources, data collection techniques, data analysis, subject, and time allocation (Gall, Gall, \& Borg, 2007).

Quasi-experimental research or pseudo-experiments take the subject of research in humans. Quasi experimental research by determining control class and experiment class using pretest value. In this design the experimental class and control class get a one-time test, ie post-test. Both of these classes in the learning process get the same treatment in terms of Purpose and content of the subject matter (Endang, 2012). The difference between the two classes is the use of historical model based on Wujil's Wukil values of collaboration model Numbered-Head Together (NHT) in the experimental class, while the control class learning using conventional learning.

Researchers made SMA Wahid Hasyim Model Karanggeneng Lamongan as a place of research caused by Lamongan is one of the developing regions in Indonesia that still need the pattern of noble values education of the nation. In addition, to support the theory that has been described by researchers at the beginning with the perceptions of experience from students in Wahid Hasyim High School Karanggeneng Lamongan model that comes from various regions that require historical learning based on local wisdom values that are still rarely taught in formal schools. 


\subsection{Effectiveness Model-Based Learning History Values Approach Suluk Wujil with Model Numbered-Head Together (NHT)}

Supriatna (2009) the successful completion of the formation of this development will assist individuals in completing the task development the next. Conversely, failure to achieve the development of this period would hamper completion of the development in the next period. Kuntowijoyo (2013) argues lessons contain moral messages that should have a different approach, so history is not boring because a lot of repetition. Lessons in high school history lessons should start rationalized, delivered must develop critical attitude of learners. Learners are required to be able to think why it happened, what exactly happened, and where the incident.

Increased social solidarity learners obtained from questionnaires distributed prior to the implementation of the model and after implementation of the model. While the level of effectiveness of the learning model should perform statistical tests and use the help of SPSS 22. Prior to testing the effectiveness of implemented, to determine the experimental class and control class has the same variant test equality. The results of the SPSS statistical test shows F value of 1.775 with a significance level of 0.550 greater than $0.05(0.550>0.05)$, the conclusion experimental class and control have the same variants. While the test results obtained by value $t$ at 638 with a significance level of 1.513 greater than 0.05 (1.513>0.05), the conclusion of competence mean value of the two classes together. Statistical analysis showed there are differences between the mean attitude after the implementation of the implementation of the experimental and control classes showed a mean value of post test experimental class of 95,5 dan control class is 86.5. While the test results $\mathrm{T}$ obtained a value of 0.560 with a significance level of $0.000(0.000<0.025)$ for the value of $\mathrm{T}$ test with significance level smaller mean the conclusion there is a difference between the attitude of the experimental class and control class.

The effectiveness of the learning model based on historical values of Suluk Wujil in improving learners' achievements known through statistical tests using the help of SPSS 22. dilakukkan equality test to determine if the experimental class and the control class is derived from variants same. Based on statistical test SPSS, F value of 2.436 with a significance level of 0,335 is greater than $0.05(0.335>0.05)$. Class experimental and control have the same variants. While the t-test, obtained a value of 1.754 with a significance level of 0.355 greater than $0.05(0.335>0.05)$, the results can be said to mean both classes of equal competence. Based on the test results with the help of statistical program SPSS 22, obtained a mean post test experimental class of post-test 88.65 and 79.5 big control of class. As for the T test obtained by value of 5.689 with a significance level of $0.000(0.000<0.025)$, a result Ho is rejected or there is a mean difference between experimental class and control class.

\section{Discussion}

\subsection{The Concept of Transformation Values Education to Increase Social Solidarity Character}

At this stage the researcher will test the implementation of the product development. Implementation test is done at SMA Wahid Hasyim Model Lamongan. Implementation of history learning based on Suluk Wujil values with Numbered-Head Together (NHT) model using Competency Standards (SK): Analyzing the nation's journey in the time of traditional countries. 1.5 Basic Competence (KD): Analyzing the process of interaction between local traditions, Hindhu, Buddhism and Islam in Indonesia. The material used at this stage is the cultural interaction between local traditions, HinduismBuddhism, and Islam in Indonesia. Selection Time of implementation implementation is adjusted with syllabus which has been prepared by subject matter teacher, so that implementation of implementation does not disturb material prepared by teacher and researcher only add information needed by student. Implementation was carried out in the experimental class obtained from the two classes of pretest ie XI IPS 1 and XI IPS 2. The results from Pretest showed class XI IPS 2 as experimental class, while class XI 
IPS 1 as control class. Assessment of the results of the implementation of the implementation test carried out during the learning process.

\subsubsection{First: Introduction}

Learning begins by praying first. The teacher can lead a prayer or ask one of the students to lead. Teachers convey the purpose and model of learning so that students are able to understand the learning process that will be done at each meeting. Teachers provide motivation and apperception that make students enthusiastic about the material to be delivered. The teacher conveys the scope of the material to be learned about the traditional, Hindu-Buddhist and Islamic development process in Indonesia and the visual images of the material, so that students can know the material in outline. At the delivery stage of material coverage, initial knowledge of Suluk Wujil is also explained to the students. The teacher gives a pretest to know the level of students' understanding of the material to be submitted and to give a questionnaire.

\subsubsection{Second: Grouping}

Grouping is done so that students are ready to receive material from teachers. In each group each consists of 4-5 students. With this grouping teachers can be easy to organize students in the delivery of material. Teachers form groups performed randomly, and Review issues according to topics discussed with exploration from various sources according to the group. Grouping also enables students to learn to accept and cooperate with group members.

\subsubsection{Third: Planning}

The material given relates to the topic taught as a whole and the student chooses one of the content values in Suluk Wujil. Teachers provide stimulus so that all students can learn together. The material delivered is more emphasized on the meaning contained in Suluk Wujil, so as to enrich and facilitate students' understanding on Suluk Wujil material. Students pay attention to the material explanation of the cultural result of the interaction process between tradisilokal, Hindu-Buddhism and Islam in Indonesia with enthusiasm. The student responds to the questions given by the teacher according to the value he or she selects. Students select the Wujil Wisdom values and give an argument for their choice. Students pay attention and receive problem solving problems from the teacher.

\subsubsection{Fourth: Organizing and Rewarding}

Guiding students in analyzing materials related to issues in discussion and observing the interaction of all group members, as well as explanation of learning resources. The teacher guides the group to analyze the issues discussed. Teachers encourage students to organize their small groups, and appreciate the value they choose. Students each sought information, gathered learning resources, analyzed the topics discussed and appreciated the opinions of all members of the group. Students seek information from various sources. Students analyze the issues discussed. Students organize their small groups, and appreciate the value that the whole group chooses. 


\subsubsection{Fifth: Numbering, Discussion of Results, Evaluation and Doing}

Provide an opportunity for each group to answer the question of the results of the discussion according to the number of questions with the number of individuals distributed. Numbering is shared at this stage, as it keeps the atmosphere conducive to learning. Provide an opportunity for students to be active in discussion activities. In the delivery of the results of the discussion all members of the group have their respective roles in accordance with the number obtained by each individual in the group. Guiding students to reflect, review, evaluate, and revise in the discussion process. Directs students to act and repeat behavior according to the value of choice based on the Suluk Wujil value as a learning material for daily life. Teachers provide evaluation of student learning and attitude assessment. Students answer questions of their group work according to the number of questions with the number of individuals distributed. Students are active in discussion activities and collect group work for teachers. Students perform reflection, review, evaluation, and revision in the discussion process. Provide examples of actions based on values that have been analyzed and formulated in discussions based on the Suluk Wujil values as learning materials. Students work on learning evaluations and fill out an attitude assessment questionnaire.

\subsubsection{Sixth: Summing up}

Students conclude the material that has been learned at this meeting. Providing value strengthening to implement the value of solidarity in social life. Provide feedback on learning processes and outcomes with the hope of integrating the values contained in Suluk Wujil to have social solidarity and to provide Appreciation of value appreciation. Lead the prayer. Students together conclude the material that has been learned by showing the strengthening of the value to implement the value of solidarity in community life. Students receive feedback by integrating the values contained in the values contained in the Suluk Wujil to be applied in each of their personalities in social solidarity and awarded for value reinforcement. Students pray according to their beliefs.

The overall results of the observations indicate that the teacher can provide stimulus to the student's initial activities by displaying images that correspond to the material. Students from the beginning will pay attention to the delivery process of the material, because it has been focused from the beginning of the learning process. The teacher explains the outline of the material that can make students pay attention to the learning process. Stages of learning model can be explained in more detail, so that students can prepare the steps that will be used in the learning process.

At the core stage of the activity, the Teacher can condition all group members into a group discussion. Through the observations made by researchers, teachers have understood the learning model that is able to optimize the role of all members in the group. Teachers can guide and direct in order to realize the creation of good cooperation between fellow students, as well as students with teachers. In the process of elaboration students are able to explore their knowledge, so that the learning process that researchers expected to have run in accordance with the purpose of research.

The process of closing learning appeared active students in giving conclusions and answer questions The end given by the teacher about social solidarity can be answered well. Students are able to explain the values of Suluk Wujil and its implementation in the life of society. Students begin to ask about the material to be delivered at the upcoming meeting.

The Education of Wujil's Wisdom Values for promoting social solidarity is described as follows: First, loyalty is a clear feeling to his mind and pure obedience to his ruler. Every process of learning in the classroom, students should always listen and try to understand the material discussed. Curiosity provides 
the motivation to always learn. According to Hasibuan loyalty is reflected by the individual's willingness to maintain and defend the organization inside and outside the work of the irresponsible person (Hasibuan, 2011). Loyalty keeps an individual on the go even if the burden he wears is heavier. Self identity is the understanding and ability to adapt to oneself, its roles in social life (family or society), workplace, and religious values (Desmita, 2006).

Second, actions that always want to provide assistance to others and communities in need. When students follow learning activities should help each other in the process of understanding the discussion material presented. When given the assignment by the teacher in the classroom, I try to actively participate boldly to criticize the wrong answer. At the time of the student Conduct group discussion activities, students should participate in group work actively and creatively by collecting various learning resources. When in school will hold a perkitan, as a student should I always help activities with friends for the implementation of the event well. Behavior helps also be interpreted as an act that benefits others without having to benefit the helper directly (Sarwono \& Meinarno, 2009).

Third, carry out his duties and obligations, which he should do, to himself, society, environment (nature, social and culture), the state and God Almighty. At the time of the learning process in the classroom, students should keep the spirit with a form of unyielding attitude in following matei all the learning until the end of the learning process. In undergoing the process of school activities, students should keep on vibrant, not lazy and never give up by always coming in every activity. When the teacher assigns tasks related to the material discussed, I always try to keep the spirit and do not know give up in doing all the lessons as a learning process. When my test score is not good, I should as a student keep trying to learn every day. Responsibility is the attitude and behavior of a person to perform duties and obligations, which he should do to self, society, environment, State and God AlmightyAnas (Salahudin, 2013).

Fourth, respect the differences of religion, ethnicity, ethnicity, opinions, attitudes, and actions of others different from himself. At the time of learning activities students should appreciate each other by keeping the atmosphere of the class remains conducive. When conducting group discussion activities, students should participate in group work actively and creatively by gathering various learning resources. When students do discussion activities I should pay attention and appreciate by listening and participating actively in discussions. When there is a division of members of the group discussion activities, I am willing to accept the results of the division of group members. Tolerance as an appreciation of diversity or diversity. Student indicator of the character of tolerance. First, can appreciate different opinions. Secondly, it can interact with people from different cultural backgrounds, beliefs and tribes. Third, do not judge people of differing opinions, beliefs or cultural background. Fourth, do not dominate or want to win alone (Raka, 2011).

\section{Conclusion}

In developing the learning model by using 3 important steps, starting from (1) analyzing the learning needs, (2) developing the learning model and the material in the research, and (3) the final stage of revision and evaluation, - Suluk Wujil values to improve students' social solidarity. The following is the result of reinterpretation of Suluk Wujil values:

1) Faithfulness is a clear feeling to his mind or pure obedience to his self-control and the entire universe in which man resides, as well as a sense of obedience to the prevailing norms.

2) Sincerity is to leave riya in various obedience with sincere feelings. Sincere contains cleansing of the liver from impurities that can muddle its properties 
3) The religious value (Piety) is morals to the creator who means obedience and love to Him, obeying means carrying out his commandments and avoiding his prohibitions which are accompanied by submission and submissive to Him.

4) Responsibility that is about someone who does anything should be based on Responsibility. Because this meaning teaches someone to take responsibility with what he has done.

5) Honesty (Self Identification) is about someone who does anything should be based with honesty, because honesty can be seen from the circumstances that will be experienced. In this case can be reinforced with a translation on this stanza that tells about the honesty that Wujil did by likening to stretching the body and can be said to be honest with him.

In learning history students should be more active and willing to learn independently various cultural heritage of Indonesian society. Understanding the values contained in the Heritage by applying it in everyday life. The attitude of social solidarity is the foundation of the life of nation and state, so that students are expected to always maintain the attitude of social solidarity in life. The educational transformations that have been related to Suluk Wujil are: first, loyalty is a clear feeling Against his thoughts and pure obedience to his ruler. Second, actions that always want to provide assistance to others and communities in need. Third, carry out his duties and obligations, which he should do, to himself, society, environment (nature, social and culture), the state and God Almighty. And fourth, respect the differences of religion, ethnicity, ethnicity, opinions, attitudes, and actions of others different from himself.

The use of innovative learning model can make the learning process more increase student enthusiasm in implementing learning. Teachers are more creative in teaching history, because history lessons still require an in-depth analysis to understand a historical event. With the use of creative learning models students can learn new things, especially the themes of historical manuscripts that can be developed in historical learning. Schools can accommodate the literary needs of historical relics. Student insights on the history of the relics will be broad if supported by literature that can accommodate teachers in the use of relic material to incorporate them into historical themes into the learning program.

\section{References}

Achmad, S.W. Esiklopedia Kearifan Jawa (Menggali Mutiara Kearifan Jawa Beradasarkan Karya Agung Para Pujangga).Yogyakarta: Araska, 2014.

Apriana, R. "Nilai Religiusitas Serat Suluk Wujil Dalam Serat Suluk Warni-Warni Karya Hamengkubuwana V," Jurnal Program Studi Pendidikan Bahasa dan Sastra Jawa Universitas Muhammadiyah Purworejo, Vol. 07, No. 04, (Oktober 2015), 23-33

Chaplin, J.P. Kamus Lengkap Psikologi. Jakarta: Rajagrafindo, 2011.

Desmita, Psikologi Perkembangan. Bandung. Remaja Rosdakarya, 2006.

Endang Mulyatiningsih, Metode Penelitian Terapan Bidang Pendidikan. Bandung: Alfabeta, 2012.

Gall, M.D., Gall, J.P., dan Borg, W.R. Educational Research: An Introduction. Boston: Allyn\&Bacon, 2003. 
Garvey, Brian\&Krug, Mary. Model-Model Pembelajaran Sejarah di Sekolah Menengah. Yogyakarta: Ombak, 2015.

Ghazali, Adeng Muchtar. Ilmu Studi Agama. Bandung: Pustaka Setia, 2015.

Hasan, S.H, dkk. Pengembangan Pendidikan Budaya dan Karakter Bangsa, Bahan Pelatihan Penguatan Metodologi Pembelajaran Berdasarkan Nilai-Kajian Moral dan nilai Budaya untuk Membentuk Daya Saing dan Karakter Bangsa. Jakarta: Puskur Balitbang Kemendiknas, 2010.

Hasibuan, M.S.P, Manajemen sumber daya Manusia (edisi revisi). Jakarta: Bumi Aksara, 2011.

Kamanto, S. Pengantar Sosiologi (Edisi Revisi). Jakarta: Lembaga Penerbit Fakultas Ekonomi Universitas Indonesia, 2004.

Khaldun, I. Muqoddimah (Ter. Ahmadie Thaha). Jakarta: Pustaka Firdaus, 2000.

Kuntowijoyo. Metodologi Sejarah. Yogyakarta. Tiara Wacana 2006.

------------. Penjelasan Sejarah (Historical Explanation). Yogyakarta. Tiara Wacana, 2008.

------------. Pengantar Ilmu Sejarah. Yogyakarta: Tiara Wacana, 2013.

Majid, Abdul. Strategi Pembelajaran. Bandung: PT Remaja Rosdakarya, 2014.

Maria. Rancangan Modul Pelatihan Orientasi Masa Depan Bidang an Pada Siswali Kelas X SMA ' $X$ ' (Bandung: Fakultas Psikologi Universitas Kristen Maranatha, Thesis, 2008).

Maryani, E\&Syamsuddin, H. "Pengembangan Modal Pembelajaran IPS untuk Meningkatkan Kompetensi Keterampilan Sosial,” Jurnal Penelitian, vol. 9, no. 1 (April 2009).

Nasution, Harun. Pembaharuan Dalam Islam: Sejarah Pemikiran dan Gerakan. Jakarta: Bulan Bintang, 1987.

Permana, C.E. Kearifan lokal masyarakat baduy dalam mengatasi mitigasi Bencana. Jakarta: Wedatama Widya Sastra, 2010.

Pujileksono, S. Pengantar Antropologi. Malang: UMM Press, 2009.

Purbatjaraka. Ajaran Rahasia Sunan Bonang: Suluk Wujil. Jakarta: Proyek Penerbitan Buku Sastra Indonesia dan Daerah, 1985.

Putra, N, Research \& Development Penelitian dan Pengembangan Suatu Pengantar. Jakarta: Rajawali Pers, 2012.

Raffles, T.S. The History Of Java. Yogyakarta: Narasi,2014.

Raka. Pendidikan Karakter Di Sekolah. Jakarta: PT Rineka Cipta 2011.

Salahudin, Anas. Pendidikan Karakter Berbasis Agama \& Budaya Bangsa. Bandung: Pustaka setia, 2013. 
Sariyatun. Model Pembelajaran IPS Berbasis Nilai Budaya Lokal Batik Klasik untuk Meningkatkan Jati Diri Bangsa Studi pada Siswa SMP di Kota Surakarta. Tesis. Universitas an Indonesia, 2012.

Sarwono, Sarlito W., dan Meinarno, Eko A., Psikologi Sosial. Jakarta: Salemba Humanika, 2009.

Seckin, Kuban. IRK BITIG: an Ideological Fortune Book in The Construction of Social Good and Bad. Uluslararas1 Türkçe Edebiyat Kültür Eğitim Dergisi Sayı: 4/4 2015 s. 1433-1450, TÜRKIYYE.

Supriatna, Dkk. Penelitian Untuk Guru Bahasa. Bekasi: Adhi Aksara Abadi Indonesia, 2009.

Susetya, W. Ular-Ular Manten. Yogyakarta: Narasi, 2007.

Warsito. Antropologi Budaya. Yogyakarta: Ombak Dua, 2015.

Wibowo, A\&Purnama, S. Pendidikan Karakter di Perguruan Tinggi. Yogyakarta: Pustaka Pelajar, 2013.

Widja, I.G. Sejarah Lokal suatu Perspektif dalam Pengajaran Sejarah. Jakarta: Departemen Pendidikan dan Kebudayaan, Direktorat Jenderal pendidikan Tinggi, 1989.

Widia, A.D. Analisis Kualitas LKS Mata Pelajaran IPS Sejarah Kelas VIII Semester II di Kota Malang. Malang: Jurusan Sejarah Fakultas Ilmu Sosial Universitas Negeri Malang, Skripsi, 2011.

Yusuf, Syamsu. Psikologi Perkembangan Anak dan Remaja. Bandung: Remaja Rosdakarya, 2012.

\section{Copyrights}

Copyright for this article is retained by the author(s), with first publication rights granted to the journal.

This is an open-access article distributed under the terms and conditions of the Creative Commons Attribution license (http://creativecommons.org/licenses/by/4.0/). 